\title{
Pengaruh Bauran Pemasaran terhadap Keputusan Pembelian Produk Olahan Burung Belibis (Dendrocygna arcuata) di Rumah Makan Melati Amuntai
}

\section{(Marketing Mix Influence to Purchasing Decisions of Processed Products of Grouse (Dendrocygna arcuata) in Melati's Restorant Amuntai)}

\author{
Azwar Saihani ${ }^{1)}$ \& Aghrei Chisasmi ${ }^{2}$ \\ Program Studi Agribisnis, Sekolah Tinggi Ilmu Pertanian Amuntai \\ 1)Azwar.saihani63@yahoo.com \\ 2)agrimi@gmail.com
}

\begin{abstract}
ABSTRAK
Tujuan penelitian adalah untuk (i) mengetahui seberapa besar pengaruh dari bauran pemasaran terhadap keputusan pembelian produk khususnya produk olahan burung Belibis (ii) mengetahui manakah dari faktor bauran pemasaran yang meliputi produk, tempat, promosi dan harga yang memiliki pengaruh dominan terhadap keputusan pembelian produk olahan burung Belibis. Teori yang digunakan adalah manajemen pemasaran yang menyangkut strategi bauran pemasaran dan perilaku konsumen. Pendekatan dalam penelitian ini adalah studi kasus yang mendukung survei. Jenis penelitian ini adalah deskriptif kuantitatif. Populasi dalam penelitian ini adalah 1500 konsumen dalam satu bulan. Ukuran sampel dalam penelitian ini adalah 94 konsumen. Data dikumpulkan dengan kuesioner. Pengujian hipotesis menggunakan analisis regresi linier berganda, yaitu uji $F$ (serempak), uji $t$ (parsial) berusaha untuk mengetahui secara simultan dan parsial pengaruh variabel independen terhadap variabel dependen pada tingkat kepercayaan 95\% $(\alpha=0,05)$. Hasil penelitian menunjukkan bahwa variabel strategi bauran pemasarn yang terdiri dari produk, harga, tempat, dan promosi secara serempak berpengaruh nyata terhadap keputusan pembelian produk olahan belibis Rumah Makan Melati Amuntai. Secara parsial hanya satu variabel independen tidak berpengaruh terhadap pembelian keputusan, variabel harga. Variabel yang paling dominan adalah promosi (25,7\%). Koefisien determinasi (R2) menunjukkan bahwa variabel independen yang diteliti mampu menjelaskan 41,1\% dari variabel keputusan pembelian sedangkan sisanya 58,9\% dijelaskan oleh variabel independen lainnya yang tidak termasuk dalam penelitian ini.
\end{abstract}

Kata kunci: Bauran, strategi, pemasaran,keputusan, pembelian.

\section{ABSTRACT}

This aims research to (i) determine how much of the marketing mix to influence purchasing decisions of products especially processed products of grouse. (ii) Determine which of the marketing mix factors that include product, place, promotion and price that has a dominant influence the purchasing decisions of processed product of grouse. The theory used is the Marketing Management coneerning Marketing Mix Strategy and Consumer Behavior. The approach in this research is a case study that supported the survey. Type of this research is descriptive quantitative. The population in this research are 1500 consumers in one month. The sample size in this researt are 94 consumers. The data were collected by questionnaire. The hypothesis testing using multiple linear regression analysis, the $F$ test (in unison), $t$ test (partial) sought to determine simultaneously and partially the effect of independent variables on the dependent variable at the $95 \%$ confidence level $(\alpha=0.05)$. The results show that the strategy of marketing mix consists of product, price, place, and promotion simultaneously significantly influence to purchasing the decisions of prossed products of grouse by consumers in Amuntai. Partially only one independent variable are not significantly influence to purchasing the decisions, the price variable. Most dominant variable is promotion (25.7\%). The coefficient of determination $\left(R^{2}\right)$ indicates that the independent variable under study is able to explain $41.1 \%$ of the purchase decision variable while the remaining $58.9 \%$ is explained by other independent variables were not included in this research.

Keywords: Mix, strategy, marketing, decisions, purchasing. 


\section{PENDAHULUAN}

Menu olahan burung belibis terbilang kuliner khas Amuntai, tidak seperti itik, menu belibis goreng atau bakar hanya tersedia di beberapa tempat tertentu. Citra rumah makan yang menyajikan olahan makanan khas daerah perlu tetap dipertahankan. Salah satu rumah makan yang menyajikan olahan makanan khas daerah seperti olahan makanan burung belibis adalah rumah makan "Melati". Rumah makan ini memilih konsep rumah makan lesehan dengan mempertahankan produk olahan belibis sebagai menu andalan.

Para pemilik rumah makan yang menyajikan olahan makanan khas daerah dikatakan perlu merancang strategi pemasaran agar mencapai tujuan pemasaran di pasar sasaran dalam pemutusan pembelian konsumen. Dalam satu bulan rata rata penjualan produk olahan burung belibis di rumah makan "Melati" adalah 1.500 porsi. Data jumlah konsumen yang melakukan transaksi produk olahan belibis di rumah makan "Melati" selama lima tahun terakhir dapat dilihat pada Tabel berikut ini.

Tabel 1. Data konsumen produk olahan burung belibis

\begin{tabular}{lccl}
\hline No & Tahun & Jumlah pembelian (porsi) & Keterangan \\
\hline 1 & 2009 & 18.000 sampai 18.500 & Kisaran data \\
2 & 2010 & 18.500 sampai 19.000 & Kisaran data \\
3 & 2011 & 17.500 sampai 18.000 & Kisaran data \\
4 & 2012 & 19.500 sampai 20.000 & Kisaran data \\
5 & 2013 & 18.500 sampai 19.000 & Kisaran data \\
\hline
\end{tabular}

Sumber : Survei lapangan, 2014.

Fluktuasi terjadi pada jumlah konsumen yang membeli produk olahan burung belibis. Perkembangan Rumah Makan "MELATI" selama lima tahun terakhir tidak berkembang secara signifikan. Diduga karena rendahnya keputusan pembelian yang dilakukan oleh konsumen. Strategi dalam pemasaran penting untuk diperbaharui yaitu dengan cara meningkatkan kinerja bauran pemasaran.

Jika setiap pengusaha rumah makan mengaplikasikan aspek-aspek dari bauran pemasaran maka sebuah rumah makan akan mampu bertahan dalam menghadapi persaingan yang ketat dan mampu meningkatkan minat beli konsumen agar penjualan terus meningkat. Berdasarkan uraian di atas maka penulis tertarik untuk meneliti pengaruh bauran pemasaran terhadap keputusan pembelian produk olahan burung belibis di Rumah Makan Melati.

Tujuan penelitian (i) mengetahui seberapa besar pengaruh dari bauran pemasaran terhadap keputusan pembelian produk khususnya produk olahan burung belibis (ii) mengetahui manakah dari faktor bauran pemasaran yang meliputi produk, tempat, promosi dan harga yang memiliki pengaruh dominan terhadap keputusan pembelian produk olahan burung belibis.

\section{METODE PENELITIAN}

\section{Tempat dan Waktu Penelitian}

Penelitian ini bertempat di Rumah Makan Melati Amuntai, pada bulan Mei Agustus 2014 mulai dari tahap persiapan, pengumpulan data, sampai dengan penyusunan laporan.

\section{Metode Pengumpulan Data}

Teknik pengumpulan data yang digunakan oleh penulis dalam penelitian ini adalah wawancara dan kuesioner. Wawancara diajukan kepada pihak pemilik rumah makan dan responden untuk mendapatkan data serta keterangan yang menunjang analisis penelitian. Sedangkan kuesioner diberikan kepada konsumen pengunjung rumah makan. Data yang dikumpulkan berupa data kualitatif 
yang dikuantitatifkan dengan pemberian bobot pada setiap pernyataan, yaitu sebagai berikut :

$$
\begin{aligned}
& \mathrm{SS}=\text { Sangat Setuju } \\
& \mathrm{S}=\text { Setuju } \\
& \mathrm{KS}=\text { Kurang Setuju } \\
& \mathrm{TS}=\text { Tidak setuju }
\end{aligned}
$$

STS $=$ Sangat Tidak setuju (1)

Penulis memberikan batasan kunjungan konsumen yang ingin diteliti dengan tujuan untuk mempermudah penelitian. Bulan kunjungan konsumen yang akan diteliti dibatasi untuk satu bulan saja, yaitu sebanyk 1500 konsumen dalam satu bulan. Metode yang digunakan dalam pengambilan sampel yaitu metode Random Sampling (secara acak). Jumlah sampel yang diambil pada penelitian ini ditentukan dengan rumus Slovin sebagai berikut (Umar, 2004) :

Dimana:

$$
\mathrm{n}=\frac{N}{1+N \cdot e^{2}}
$$

$$
\begin{aligned}
& \mathrm{N}=\text { jumlah seluruh anggota populasi } \\
& \mathrm{n}=\text { jumlah sampel } \\
& \mathrm{e}=\text { Tingkat kesalahan }(10 \%) \\
& \quad \mathrm{n}=\frac{1500}{1+1500(0,01)}=93,75(94 \text { sampel })
\end{aligned}
$$

\section{HASIL DAN PEMBAHAAN}

\section{Hasil}

\section{Identitas Responden}

Penelitian mengenai pengaruh bauran pemasaran terhadap keputusan pembelian produk olahan burung belibis di rumah maka melati, mengambil tempat di rumah makan melati yang penulis lakukan selama 11 hari. Karakteristik responden yang diwawancarai dalam penelitian ini meliputi alamat, jenis kelamin, usia,

\begin{tabular}{|c|c|c|}
\hline Pendapatan Rp/bln & Frekuensi & Persentase \\
\hline$\leq 4.000 .000$ & 70 & 74,46 \\
\hline $4.000 .000-8.000 .000$ & 13 & 13,82 \\
\hline$\geq 8.000 .000$ & 11 & 11,7 \\
\hline Total & 94 & 100 \\
\hline
\end{tabular}
pendapatan per bulan, pekerjaan.

a. Karakteristik konsumen olahan belibis berdasarkan alamat

\begin{tabular}{lcc}
\hline Alamat & Frekuensi & Persentase \\
\hline Amuntai & 8 & 8,5 \\
Luar Amuntai & 86 & 91,4 \\
\hline Total & 94 & 100 \\
\hline
\end{tabular}

b. Karakteristik konsumen olahan belibis berdasarkan jenis kelamin

\begin{tabular}{lcc}
\hline Jenis Kelamin & Frekuensi & Persentase \\
\hline Laki-Laki & 63 & 67 \\
Perempuan & 31 & 32,9 \\
\hline Total & 94 & 100 \\
\hline
\end{tabular}

c. Karakteristik Konsumen Olahan Belibis Berdasarkan Usia

\begin{tabular}{ccc}
\hline Usia & Frekuensi & Persentase \\
\hline$\leq 20$ & 9 & 9,5 \\
$21-30$ & 27 & 28,72 \\
$31-40$ & 36 & 38,29 \\
$40-50$ & 15 & 15,9 \\
$>50$ & 7 & 7,44 \\
\hline Total & 94 & 100 \\
\hline
\end{tabular}

d. Karakteristik konsumen olahan belibis berdasarkan pendapatan per bulan

e. Karakteristik konsumen olahan belibis berdasarkan pekerjaan 


\begin{tabular}{|c|c|c|}
\hline Pekerjaan & Frekuensi & Persentase \\
\hline PNS & 27 & 28,7 \\
\hline Karyawan & 6 & 6,38 \\
\hline Wiraswasta & 30 & 31,9 \\
\hline Ibu rumah tangga & 5 & 5,31 \\
\hline Lain - lain & 26 & 27,6 \\
\hline Total & 94 & 100 \\
\hline
\end{tabular}

Uji Validitas dan Reabilitas

Berikut disajikan tabel uji validitas dan reliabilitas Rumah Makan Melati terhadap beberapa variabel pada Tabel 2 .

Tabel 2. Uji validitas dan reliabilitas Rumah Makan Melati terhadap beberapa variabel

\begin{tabular}{|c|c|c|c|}
\hline No & Pernyataan & Validitas & Reliabilitas \\
\hline & \multicolumn{3}{|l|}{ Variabel Produk $\left(\mathrm{X}_{1}\right)$} \\
\hline 1 & Rasanya lezat/enak & 0,433 & 0,74 \\
\hline 2 & Porsinya sesuai dengan keinginan & 0,396 & 0,74 \\
\hline 3 & Produk higenis/bersih & 0,68 & 0,73 \\
\hline \multirow[t]{2}{*}{4} & Pelayanan baik & 0,623 & 0,73 \\
\hline & \multicolumn{3}{|l|}{ Variabel Harga $\left(\mathrm{X}_{2}\right)$} \\
\hline 5 & Harga produk sesuai semua kalangan & 0,558 & 0,73 \\
\hline 6 & Harga produk sesuai dengan kualitas & 0,705 & 0,73 \\
\hline \multirow[t]{2}{*}{7} & Sesuai dengan harga olahan belibis di tempat lain & 0,558 & 0,73 \\
\hline & \multicolumn{3}{|l|}{ Variabel lokasi/tempat $\left(\mathrm{X}_{3}\right)$} \\
\hline 8 & Lokasi mudah dikunjungi & 0,517 & 0,74 \\
\hline 9 & Ruangan yang bersih & 0,583 & 0,73 \\
\hline \multirow{3}{*}{$\begin{array}{l}10 \\
11\end{array}$} & Tempatnya sangat nyaman dan dekorasinya bagus & 0,655 & 0,73 \\
\hline & $\begin{array}{l}\text { Fasilitas pendukung lengkap (musik,kipas angin,TV,areal } \\
\text { parkir,dll) }\end{array}$ & 0,588 & 0,73 \\
\hline & Variabel promosi $\left(\mathrm{X}_{4}\right)$ & & \\
\hline \multirow[t]{2}{*}{12} & Diketahui dari teman/kerabat & 0,583 & 0,73 \\
\hline & Variabel Keputusan Pembelian (Y) & & \\
\hline 13 & Anda sudah mantap untuk membeli & 0,537 & 0,74 \\
\hline 14 & $\begin{array}{l}\text { Anda akan memberi saran kepada orang lain untuk datang dan } \\
\text { membeli }\end{array}$ & 0,668 & 0,73 \\
\hline 15 & Anda akan datang lagi dan membeli produk ini & 0,612 & 0,73 \\
\hline
\end{tabular}

\section{Pengujian Asumsi Klasik}

\section{Uji Normalitas}

Hasil pengujian normalitas data dapat dilihat pada Gambar 1 berikut :

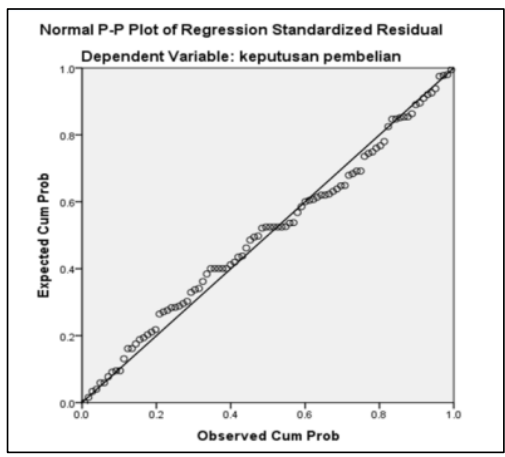

Gambar 1. Hasil pengujian normalitas data

Berdasarkan gambar di atas dapat dilihat data yang digunakan menunjukkan indikasi normal. Analisis dari grafik di atas terlihat titik-titik menyebar disekitar garis 
Azwar Saihani \& Agrei Chisasmi, Pengaruh bauran pemasaran terhadap...

diagonal, serta penyebarannya mengikuti arah garis diagonal. Maka model regrsi layak dipakai untuk memprediksi keputusan

\section{Uji Multikoliniearitas}

Dari Tabel 3 berikut menunjukkan bahwa tidak ada satu variabel independen yang memiliki nilai tolerance lebih dari 1 , berarti pembelian berdasarkan masukan veriabel independen.

Tabel 3. Hasil Uji Multikoliniearitas

tidak ada korelasi Antara variabel independen. Hasil perhitungan nilai VIF menunjukkan tidak ada satu variabel

\begin{tabular}{ccc}
\hline \multirow{2}{*}{ Model } & \multicolumn{2}{c}{ Collinearity Statistics } \\
\cline { 2 - 3 } & Tolerance & VIF \\
\hline Produk & .706 & 1.416 \\
Harga & .619 & 1.616 \\
Tempat & .661 & 1.512 \\
Promosi & .766 & 1.305 \\
\hline
\end{tabular}

independen yang memilki nilai VIF lebih dari 10. Jadi dapat disimpulkan bahwa tidak ada multikoloniearitas antar variabel

\section{Uji Heteroskedastisitas}

Dari Gambar 2 dibawah terlihat titik titik menyebar secara acak, tidak membentuk sebuah pola tertentu yang jelas, serta terseba baik diatas maupun dibawah angka 0 pada sumbu Y. hal ini berarti tidak independen dalam model regresi pada penelitian ini terjadi heteroskedastisitas pada model regresi, sehingga model regresi layak dipakai untuk prediksi keputusan pembelian berdasakan masukan dari variabel bebasnya.

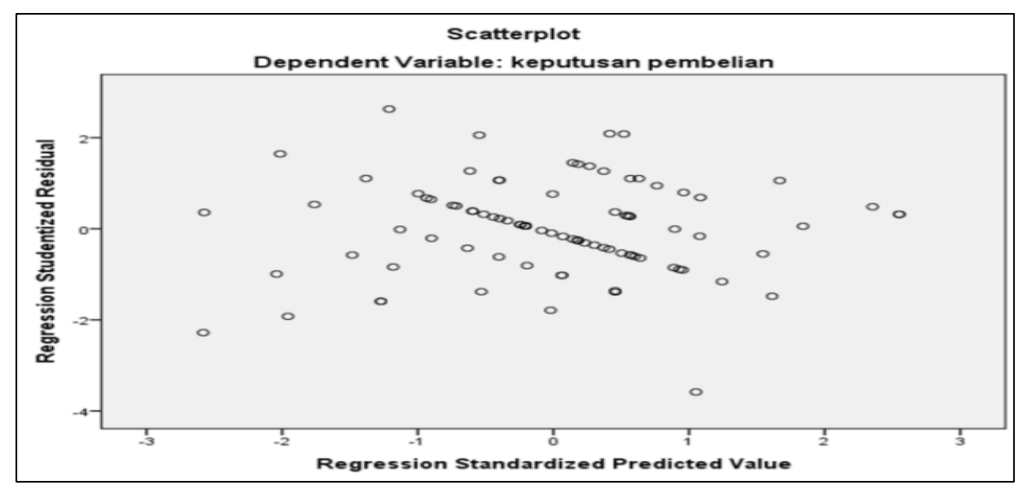

\section{Pengujian hipotesis}

Hipotesis menyatakan bahwa faktor faktor produk $\left(\mathrm{X}_{1}\right)$, harga $\left(\mathrm{X}_{2}\right)$, tempat $\left(\mathrm{X}_{3}\right)$, dan promosi $\left(\mathrm{X}_{4}\right)$. Sebagai variabel strategi bauran pemasaran berpengaruh terhadap keputusan pem belian produk olahan burung belibis oleh konsumen produk olahan burung belibis di rumah maka melati. Model yang digunakan untuk menduga pengaruh tersebut adalah :

$\mathrm{Y}=\beta_{0}+\beta_{1} X_{1}+\beta_{2} X_{2}+\beta_{3} X_{3}+\beta_{4} X_{4}$

Tabel 4. Hasil regresi bauran pemasaran terhadap keputusan pembelian. 
Coefficients $^{\mathrm{a}}$

\begin{tabular}{lccccc}
\hline \multirow{2}{*}{ Model } & \multicolumn{2}{c}{ Unstandardized Coefficients } & $\begin{array}{c}\text { Standardized } \\
\text { Coefficients }\end{array}$ & \multirow{2}{*}{$\mathrm{t}$} & Sig. \\
\cline { 2 - 4 } & $\mathrm{B}$ & Std. Error & Beta & & \\
\hline (Constant) & 1.377 & .365 & & 3.774 & .000 \\
produk & .257 & .098 & .253 & 2.609 & .011 \\
harga & .036 & .084 & .044 & .425 & .672 \\
tempat & .252 & .089 & .284 & 2.843 & .006 \\
promosi & .151 & .054 & .258 & 2.777 & .007 \\
\hline
\end{tabular}

a. Depensent Variable : Keputusan Pembelian

Berdasarkan Tabel 9 di atas, maka persamaan regresi linier berganda pada penelitian ini adalah sebaai berikut:

$\mathrm{Y}=1,377+0,257 \mathrm{X}_{1}+0,036 \mathrm{X}_{2}+$ $0,252 \mathrm{X}_{3}+0,151 \mathrm{X}_{4}$

Koefisien regresi konstanta adalah 1,377 artinya bahwa tingkat keputusan pembelian produk olahan burung belibis oleh konsumen produk olahan burung belibis dipengaruhi oleh strategi bauran pemasaran sebesar 1,377 . sedang koefisien regresi semua variabel bebas bertanda positif ini berarti bahwa faktor strategi bauran pemasaran mempunyai hubungan positif dengan tingkat keputusan oleh konsumen produk olahan burung belibis dalam membeli produk olahan burung belibis, artinya mempunyai hubunga yang searah atau dengan kata lain baiknya strategi bauran pemasaran diikuti dengan tingginya keputusan pembelian produk olahan burung belibis oleh konsumen produk olahan burung belibis.

\section{Uji F (serempak)}

Untuk menguji pengaruh strategi bauran pemasaran yag terdiri dari produk, harga, tempat, dan promosi secara serempak terhadap keputusan pembelian produk olahan burung belibis oleh konsumen prouk olahan burung belibis si rumah makan melati digunakan uji statistik $F$ (uji F). apabila nilai $F_{\text {hitung }}>$ nilai $F_{\text {tabel, }}$ maka $\mathrm{H}_{0}$ ditolak dan $\mathrm{H}_{1}$ diterima. Sebaliknya apabila nilai $\mathrm{F}_{\text {hitung }}<$ nilai $\mathrm{F}_{\text {tabel}}$, maka $\mathrm{H}_{0}$ diterima dan $\mathrm{H}_{1}$ ditolak. Hasil uji secara serempak dapat dilihat pada tabel sebagai berikut.

Tabel 5. Hasil uji serempak

\begin{tabular}{cccccc}
\multicolumn{8}{c}{ ANOVA $^{\mathrm{a}}$} \\
\hline Model & Sum of Squares & df & Mean Square & F & Sig. \\
\hline Regression & 9.976 & 4 & 2.494 & 15.524 & $.000^{\mathrm{b}}$ \\
Residual & 14.298 & 89 & 161 & & \\
Total & 24.274 & 93 & & & \\
\hline
\end{tabular}

a. Dependent Variable: keputusan pembelian

b. Predictors: (Constant), promosi, produk, tempat, harga

Dari tabel diatas diperoleh nilai $\mathrm{F}_{\text {hitung }}$ sebesar 15,524, dengan tingkat signifikan 0.000 , sedangkan nilai $\mathrm{F}_{\text {tabel }}$ pada tingkat kepercayaan $95 \%$ atau $\alpha=0,05$ adalah 2,47 . Dengan membandingkan nilai $F_{\text {hitung }}$ dengan nilai $F_{\text {tabel, }}$ maka $F_{\text {hitung }}(15,524)$ lebih besar dari nilai $F_{\text {tabel }}(2,47)$. Keputusannya adalah $\mathrm{H}_{0}$ ditolak dan $\mathrm{H}_{1}$ diterima, artinya secara serempak variabel strategi bauran pemasaran yang terdiri dari produk, harga, tempat, dan promosi berpengaruh nyata terhadap keputusa pembelian produk olahan burung belibisdi rumah makan melati.

\section{Uji t (uji parsial)}

Untuk menguji pengaruh strategi bauran pemasaran yag terdiri dari produk, harga, tempat, dan promosi secara serempak terhadap keputusan pembelian produk olahan burung belibis oleh konsumen prouk olahan burung belibis si rumah makan melati digunakan uji statistik $t$ (uji t). 
Apabila nilai $t_{\text {hitung }}>$ nilai $t_{\text {tabel }}$, maka $\mathrm{H}_{0}$ ditolak dan $\mathrm{H}_{1}$ diterima. Sebaliknya apabila nilai $t_{\text {hitung }}<$ nilai $t_{\text {tabel }}$, maka $\mathrm{H}_{0}$ diterima dan

Tabel 6. Hasil uji parsial
$\mathrm{H}_{1}$ ditolak. Hasil uji secara serempak dapat dilihat pada tabel sebagai berikut.

\section{Coefficients $^{\mathrm{a}}$}

\begin{tabular}{lccccc}
\hline \multirow{2}{*}{ Model } & \multicolumn{2}{c}{ Unstandardized Coefficients } & $\begin{array}{c}\text { Standardized } \\
\text { Coefficients }\end{array}$ & $\mathrm{t}$ & Sig. \\
\cline { 2 - 4 } & $\mathrm{B}$ & Std. Error & Beta & & \\
\hline (Constant) & 1.377 & .365 & & 3.774 & .000 \\
produk & .257 & .098 & .253 & 2.609 & .011 \\
harga & .036 & .084 & .044 & .425 & .672 \\
tempat & .252 & .089 & .284 & 2.843 & .006 \\
promosi & .151 & .054 & .258 & 2.777 & .007 \\
\hline
\end{tabular}

a. Dependent Variable: keputusan pembelian

Dilihat dari Tabel 6 di atas diperoleh nilai thitung dari setiap variabel independen dalam penelitian ini. Nilai $t_{\text {hitung }}$ dari setiap variabel independen akan dibandingkan dengan nilai $t_{\text {tabel }}$ dengan menggunkan tingkat kepercayaan $95 \%$ atau $\alpha=0,05$ maka diperoleh nilai $t_{\text {tabel }} 1,987$.

Dari hasil uji t akan diketahui pengaruh setiap variabel bebas terhadap variabel terikatnya sebagai berikut ini :

a. Pengaruh produk $\left(\mathrm{X}_{1}\right)$ terhadap variabel keputusan pembelian (Y) secara parsial dapat dilihat pada tabel 18 nilai $t_{\text {hitung }}$ $(2,609)$ lebih besar dari nilai $t_{\text {tabel }}$ $(1,987)$, maka keputusannya adalah $\mathrm{H}_{0}$ ditolak dan $\mathrm{H}_{1}$ diterima.

b. Pengaruh harga $\left(\mathrm{X}_{2}\right)$ terhadap variabel keputusan pembelian (Y) secara parsial dapat dilihat pada tabel 18 nilai thitung $(0,425)$ lebih kecil dari nilai tabel
(1,987), maka keputusannya adalah $\mathrm{H}_{0}$ diterima dan $\mathrm{H}_{1}$ ditolak.

c. Pengaruh tempat $\left(\mathrm{X}_{3}\right)$ terhadap variabel keputusan pembelian (Y) secara parsial dapat dilihat pada tabel 18 nilai $t_{\text {hitung }}$ $(2,845)$ lebih besar dari nilai $t_{\text {tabel }}$ $(1,987)$, maka keputusannya adalah $\mathrm{H}_{0}$ ditolak dan $\mathrm{H}_{1}$ diterima.

d. Pengaruh promosi $\left(\mathrm{X}_{4}\right)$ terhadap variabel keputusan pembelian (Y) secara parsial dapat dilihat pada tabel 18 nilai $t_{\text {hitung }}(2,777)$ lebih besar dari nilai $t_{\text {tabel }}(1,987)$, maka keputusannya adalah $\mathrm{H}_{0}$ ditolak dan $\mathrm{H}_{1}$ diterima.

\section{Koefisien determinasi}

Untuk menentukan kelayakan suatu model regresi, yang dilihat dari besarnya koefisien determinasi atau $\mathrm{R}^{2}$. Nilai besarnya koefisien deerminasi atau $\mathrm{R}^{2}$ dapat dilihat sebagai berikut

Tabel 7. Hasil Uji Determinasi

\begin{tabular}{ccccc}
\multicolumn{5}{c}{ Model Summary } \\
\hline 1 & $\mathrm{R}$ & R Square & Adjusted R Square & Std. Error of the Estimate \\
\hline
\end{tabular}

a. Predictors: (Constant), $\mathrm{X}_{4}, \mathrm{X}_{1}, \mathrm{X}_{3}, \mathrm{X}$

Dari htabel tersebut diketahui nilai besarnya koefisien determinasi atau $\mathrm{R}^{2}$ sebesar 0,411 artinya bahwa variabel keputusan pembelian dapat dipengaruhi oleh variabel strategi bauran pemasaran sebesar
$41,1 \%$, sedangkan sisanaya sebesar $58,9 \%$ merupakan kontribusi variabel independent lain yang tidak termasuk dalam penelitian ini.

\section{Pembahasan}

\section{a. Produk}


Berdasarkan hasil analisis regresi, variabel produk memiliki nilai koefisien regresi positif yaitu sebesar 0,257. Artinya, jika kualitas produk, rasa produk, kebersihan produk dan pelayanan ditingkatkan $1 \%$, maka akan meningkat keputusan pembelian produk olahan belibis sebesar $25,7 \%$. Sedangkan apabila kualitas produk, rasa produk, kebersihan produk dan pelayanan menurun $1 \%$, maka keputusan pembelian produk olahan belibis akan turun sebesar 25,7\%. Pada tingkat kepercayaan $95 \%$, variabel produk berpengaruh nyata terhadap keputusan pembelian produk olahan burung belibis. Ini ditunjukkan oleh nilai nilai $t_{\text {hitung }}(2,609)$ yang lebih besar dari nilai $t_{\text {tabel }}(1,987)$. Hal ini disebabkan konsumen dalam memutuskan pembeliannya didasarkan pada produk yang berkualitas seperti porsinya yang seimbang, memiliki rasa yang enak, kebersihan pada penyajian produk serta pelayanan yang baik.

Simbolon et.al., (2012) menjelaskan bahwa variabel produk mempengaruhi keputusan pembelian kartu simpati telkomsel pada mahasiswa Fakultas Ekonomi Program S1 Universitas Sumatera Utara, karena nilai thitung < tabel $(0,405$ $<$ 1,986). Menurut Kotler (1997), konsep produk tidak terbatas pada objek fisik, segala sesuatu yang mampu memuaskan kebutuhan dapat disebut suatu produk. Contohnya pelayanan, itulah mengapa pelayanan terhadap produk kapada konsumen sangat mempengaruhi keputusan pembelian.

\section{b. Harga}

Berdasarkan hasil analisis regresi, variabel harga memiliki nilai koefisien regresi positif yaitu sebesar 0,036. tingkat kepercayaan $95 \%$, nilai thitung $(2,845)$ lebih besar dari nilai tabel $(1,987)$, artinya variabel tempat berpengaruh terhadap keputusan pembelian produk olahan burung belibis. Hal ini disebabkan lokasi rumah makan melati sangat strategis, mudah dikunjungi, memiliki dekorasi yang sangat bagus dengan konsep rumah bambu, areal parkir yang luas dan ditambah dengan wahana bermain untuk anak anak.
Artinya, jika kebijakan tentang harga ditingkatkan $1 \%$, maka akan meningkat keputusan pembelian produk olahan belibis sebesar 3,6\%. Sedangkan apabila kebijakan tentang harga menurun $1 \%$, maka keputusan pembelian produk olahan belibis akan turun sebesar 3,6\%. Pada tingkat kepercayaan $95 \%$, nilai thitung $(0,425)$ lebih kecil dari nilai tabel $(1,987)$, artinya variabel harga tidak berpengaruh terhadap keputusan pembelian produk olahan burung belibis. Hal ini disebabkan harga produk olahan burung belibis di Rumah Makan Melati relatif sama dengan tempat lain dan cenderung lebih mahal. Sehingga variabel harga tidak menjadi bahan pertimbangan bagi konsumen untuk membeli produk olahan burung belibis.

Inilah yang harus diperhatikan oleh para pengusaha rumah makan. Menurut Nitisusastro (2012), jika harga yang dilekatkan terlalu mahal, maka tidak ada konsumen yang mau membeli. Sebaliknya pada harga yang dilekatkan terlalu murah akan dianggap sebagai barang murahan.

\section{c. Tempat}

Berdasarkan hasil analisis regresi, variabel tempat memiliki nilai koefisien regresi positif yaitu sebesar 0,252. Artinya, jika variabel tempat yang indikatornya terdiri dari lokasi, kebersihan, dekorasi dan fasilitas ditingkatkan 1\%, maka akan meningkat keputusan pembelian produk olahan belibis sebesar 25,2\%. Sedangkan apabila variabel tempat yang indikatornya terdiri dari lokasi, kebersihan, dekorasi dan fasilitas menurun sebesar $1 \%$, maka keputusan pembelian produk olahan belibis akan menurun sebesar 25,2\%. Pada

Hal ini sesuai dengan penelitian yang dilakukan Wijaya et. al., (2012) Hasil pengujian secara statistik menunjukkan bahwa nilai thitung $>$ ttabel yaitu $(7,933)>(3,148)$, berarti "pilihan tempat" yang terbentuk dari atribut produk saingan, kenyamanan tempat, fasilitas pendukung, jarak, kelayakan tempat (bauran pemasaran) secara bersama mempunyai pengaruh positif terhadap keputusan konsumen dalam 
pembelian produk olahan ayam di rumah makan Resto GAMA. Sedangkan berdasarkan hasil persamaan regresi didapatkan nilai koefisien dari "pilihan tempat" sebesar 0,260 yang artinya jika pilihan tempat ditingkatkan $1 \%$ saja, maka keputusan konsumen akan meningkat sebesar $26 \%$. Jika pilihan tempat diturunkan $1 \%$ saja, maka keputusan konsumen akan turun sebesar $26 \%$.

\section{d. Promosi}

Berdasarkan hasil analisis regresi, variabel promosi memiliki nilai koefisien regresi positif yaitu sebesar 0,151. Artinya, jika variabel promosi ditingkatkan $1 \%$, maka akan meningkat keputusan pembelian produk olahan belibis sebesar $15,1 \%$. Sedangkan apabila promosi menurun $1 \%$, maka keputusan pembelian produk olahan belibis akan menurun sebesar $15,1 \%$.

Pada tingkat kepercayaan 95\%, nilai $t_{\text {hitung }}(2,777)$ lebih besar dari nilai $t_{\text {tabel }}$ $(1,987)$, artinya promosi memberikan pengaruh yang signifikan terhadap keputusan pembelian produk olahan burung belibis di Rumah Makan Melati. Hal ini disebabkan rekomendasi yang baik dari teman/kerabat yang mempromosikan Rumah Makan Melati baik secara langsung maupun tidak langsung membuat para konsumen memutuskan membeli produk olahan burung belibis. Karena promosi berfungsi untuk mempengaruhi sikap dan kesukaan konsumen dalam memilih produk.

Hal ini sesuai dengan penelitian Suti (2010), Hasil pengujian secara statistik menunjukkan bahwa nilai thitung > tabel yaitu $(2,796)>(1,996)$, dengan demikian dapat disimpulkan bahawa variabel promosi berpengaruh terhadap keputusan pembelian pada konsumen handphone Esia. Sedangkan berdasarkan hasil persamaan regresi didapatkan nilai koefisien 0,223 , artinya setiap penambahan $1 \%$ variabel promosi maka akan menaikkan keputusan pembelian pada konsumen handphone Esia sebesar 22,3\%.

Secara keseluruhan variabel bauran pemasaran berpengaruh terhadap keputusan pembelian produk olahan burung belibis di
Rumah Makan Melati. Ini dibuktikan dengan hasil uji $\mathrm{F}$ yaitu $\mathrm{F}_{\text {hitung }}(15,524)$ lebih besar dari nilai $F_{\text {tabel }}(2,47)$. Hal ini disebabkan karena elemen bauran pemasan yang terdiri dari produk, harga, tempat dan promosi merupakan sebagian dari alasan konsumen melakukan pembelian produk olahan belibis. Bauran pemasaran sebagai perangkat alat pemasaran taktis yang dapat dikendalikan, dapat dipadukan oleh perusahaan untuk menghasilkan respon yang di inginkan (keputusan pembelian) dalam pasar sasaran (Kotler, 1997). Variabel bauran pemasaran dapat mempengaruhi keputusan pembelian produk olahan burung belibis sebesar $41,1 \%$, sedangkan sisanya sebesar $58,9 \%$ merupakan kontribusi variabel independent lain yang tidak termasuk dalam penelitian ini.

Diantara ke empat variabel bauran pemasaran, variabel tempat lebih mempengaruhi keputusan pembelian produk olahan burung belibis dibanding variabel lain. Konsumen memutuskan melakukan pembelian produk olahan burung belibis lebih banyak dikarenakan tempat Rumah Makan Melati sangat strategis, mudah dikunjungi dan didukung oleh berbagai fasilitas lainnya yang mungkin tidak didapatkan konsumen di rumah makan lain.

\section{KESIMPULAN}

Variabel strategi bauran pemasarn yang terdiri dari produk, harga, tempat, dan promosi secara serempak berpengaruh nyata terhadap keputusan pembelian produk olahan belibis Rumah Makan Melati Amuntai. Pada tingkat kepercayaan 95\% atau $\alpha=0,05 F_{\text {hitung }}(15,524)$ lebih besar dari nilai $\mathrm{F}_{\text {tabel }}(2,47)$. Keputusannya adalah $\mathrm{H}_{0}$ ditolak dan $\mathrm{H}_{1}$ diterima. Hasil perhitungan dengan uji $\mathrm{t}$ diperoleh nilai $\mathrm{t}_{\text {hitung }}$ untuk variabel produk $\left(\mathrm{X}_{1}\right)$ sebesar 2,609, untuk variabel harga $\left(\mathrm{X}_{2}\right)$ sebesar 0,425 , untuk variabel tempat $\left(\mathrm{X}_{3}\right)$ sebesar 2,843 dan untuk variabel promosi $\left(\mathrm{X}_{4}\right)$ sebesar 2,777, sedangkan nilai tabel sebesar 1,987. Dengan demikian variabel produk, tempat dan promosi berpengaruh terhadap keputusan pembelian produk olahan belibis. Sedangkan 
variabel harga tidak berpengaruh terhadap keputusan pembelian produk olahan belibis.

\section{DAFTAR PUSTAKA}

Kotler, P. dan Gary Armstrong. 1997. Dasar-Dasar Pemasaran. edisi Bahasa Indonesia. Prenhallindo. Jakarta.

Nitisusastro, M. 2012. Perilaku Konsumen, Dalam Perspektif Kewirausahaan. Alfabeta. Bandung.

Simbolon, Y. K. dan Marhayanie. 2012. Pengaruh strategi bauran pemasaran terhadap keputusan pembelian kartu simpati telkomsel pada mahasiswa Fakultas Ekonomi program S1 Universitas Sumatera Utara.https://jurnal.usu.ac.id/index.p hp/ jmim/article/download/2354/pdf

Suti, I. 2010. Pengaruh kualitas produk, harga dan promosi terhadap keputusan pembelian handphone esia. Skripsi Fakultas Ekonomi Dan Bisnis Universitas Islam Negeri Syarif Hidayatullah Jakarta.

Umar, H. 2004. Metode Penelitian, Untuk

Skripsi dan Tesis Bisnis. Rajawali Pers. Jakarta.

Wijaya, B. H., Hari Dwi Utami dan Bambang Ali Nugroho. 2012. Pengaruh bauran pemasaran terhadap keputusan konsumen membeli produk olahan ayam di rumahmakan Resto Gama Malang. Https:// fapet.ub.ac.id 